\title{
STUDI PERBANDINGAN KACANG MERAH (Phaseolus Vulgaris L.) DAN RUMPUT LAUT (Euchema cottonii) TERHADAP KARAKTERISTIK PERMEN JELLY
}

\author{
Moh. Amin ${ }^{(1)}$, Rifni Novitasari ${ }^{(2)}$ dan Hermiza Mardesci ${ }^{(3)}$ \\ (1) Alumni Teknologi Pangan Faperta UNISI \\ (2)(3) Dosen Teknologi Pangan Faperta UNISI \\ rifninovi@gmail.com \\ mimzaaci@yahoo.co.id
}

\begin{abstract}
Abstrak
Kacang merah (Phaseolus vulgaris L.) adalah salah satu jenis kacang-kacangan yang banyak ditemukan dan dimanfaatkan di Indonesia. Kacang merah kering merupakan sumber protein nabati, karbohidrat kompleks, serat, vitamin B, folasin, tiamin, kalsium, fosfor, dan zat besi. Rumput laut (Euchema cottonii) merupakan salah satu komoditi kelautan Indonesia yang cukup potensial sebagai penghasil devisa negara. Kadar karagenan dalam setiap Eucheuma berkisar antara 54-73\% tergantung pada jenis dan tempat tumbuhnya. Rumput laut ini digunakan dalam pengolahan permen jelly bertujuan untuk membantu tekstur dari permen jelly kacang merah, karena rumput laut mengandung karagenan. Tujuan dari penelitian ini adalah untuk mengetahui konsentrasi perbandingan antara kacang merah (Phaseolus Vulgaris L.) dan rumput laut (Euchema cottonii) yang tepat terhadap karakteristik permen jelly. Hasil dari penelitian yang telah dilakukan dengan rancangan acak lengkap (RAL), menunjukkan bahwa perlakuan terbaik terdapat pada C (kacang merah $50 \%$ dan rumput laut 50\%) dengan kadar air total $22,95 \%$, kadar gula reduksi $19,10 \%$, kadar abu 1,012 \%, dan hasil uji organoleftik rasa 4,15\%, warna 3,9\%, aroma 4,2\% dan tekstur 4,15\%. Pada pembuatan permen jelly kacang merah dan rumput laut belum menghasilkan permen dengan kadar air yang sesuai standar SNI.
\end{abstract}

Kata Kunci : Permen jelly, Kacang Merah, Rumput laut.

\section{PENDAHULUAN}

Kacang merah (Phaseolus vulgaris L.) adalah salah satu jenis kacangkacangan yang banyak ditemukan dan dimanfaatkan di Indonesia. Di Kabupaten Indragiri Hilir kacang merah mudah ditemukan dipasar. Pada tahun 2014, produksi kacang merah di Indonesia mencapai angka 100.319 ton (BPS, 2016). Kacang merah memiliki kandungan gizi yang sangat baik, hal ini sangat menguntungkan bagi kesehatan tubuh manusia apalagi jika diolah secara baik dan benar. Kacang merah kering merupakan sumber protein nabati, karbohidrat kompleks, serat, vitamin B, folasin, tiamin, kalsium, fosfor, dan zat besi (Astawan, 2009 dalam Huda, 2015).

Rumput laut merupakan salah satu komoditi kelautan Indonesia yang cukup potensial sebagai penghasil devisa negara. Kadar karagenan dalam setiap Eucheuma berkisar antara 54-73\% tergantung pada jenis dan tempat 
tumbuhnya. Lokasi budidaya rumput laut jenis ini diIndonesia antara lain: Lombok, Sumbar, Sulawesi Tenggara, Sulawesi Tengah, Lampung, Kepulauan Seribu, dan perairan Pelabuhan Ratu. Rumput laut ini digunakan dalam pengolahan permen jelly bertujuan untuk membantu tekstur dari permen jelly kacang merah, karena rumput laut mengandung karagenan (Amora, 2013).

Permen jelly adalah salah satu jenis kembang gula yang disukai oleh anak-anak karena memiliki sifat yang khas pada rasa, bentuk, kekenyalan, dan elastisitas produk. Umumnya pada pembuatan permen jelly dilakukan penambahan sari buah atau essence untuk memberikan warna atau cita rasa yang khas pada permen jelly yang dihasilkan. Bahan lain selain sari buah yaitu kacang-kacangan, sayur-sayuran dan susu bisa juga digunakan dalam pembuatan permen jelly agar memiliki nilai nutrisi yang tinggi dibandingkan dengan yang ada di pasaran hanya berasal dari penambahan esence dari bahan kimia. Permen jelly tergolong pangan semi basah, oleh karena itu produk ini cepat rusak. Penambahan bahan pengawet diperlukan untuk memperpanjang waktu simpannya. Bahan pengawet yang ditambahkan harus dalam batas tertentu yang telah ditetapkan (Koswara, 2009).

Permen jelly sudah banyak dibuat oleh beberapa industri maupun pabrik dimana pada umumnya permen jelly ini terbuat dari gelatin. Gelatin merupakan suatu produk yang di hidrolisis persial kologen yang berasal dari jaringan ikat dan tulang hewan yang berfungsi sebagai pembentuk gel, pelapis dan pengental.

Penelitian ini menggunakan kacang merah dalam proses pembuatan permen jelly. Kacang merah dipilih karena memiliki aroma dan rasa yang khas serta nilai gizi yang cukup tinggi.
Permen jelly kacang merah ini diharapkan dapat menjadi salah satu solusi dari usaha pencegahan osteoporosis sejak dini, mencegah anemia, memperkuat kekebalan tubuh, menurunkan kolestrol darah, melancarkan pencernaan, menguatkan tulang dan gigi.

Kebanyakan kacang merah dikonsumsi oleh anak-anak dan dewasa hanya pada saat diolah menjadi campuran sayur, campuran es serut (es kacang merah), sup, es krim, maupun kue. Padahal kacang merah sangat bermanfaat untuk pertumbuhan dan kecerdasan anak-anak. Kandungan protein pada kacang merah cukup tinggi yaitu berkisar 21-27\% (Rukmana, 2009).

Pemanfaatan dan pengembangan produk dari kacang merah di Indragiri Hilir belum dilakukan secara optimal, dengan demikian salah satu cara pengembangan kacang merah adalah dijadikan permen jelly. Kendala yang ditemui dalam pembuatan permen jelly ini dengan bahan baku bubur kacang merah dan bubur rumput laut adalah belum ditemukannya konsentrasi antara bubur kacang merah dan bubur rumput laut yang tepat untuk menghasilkan jelly dengan warna, aroma, dan tekstur yang diinginkan.

Dari penelitian Sriwahyuni et al. (2017), tentang studi konsentrasi bubur nipah (Nypa fruticans wurmb) dan rumput laut (Euchema cottonii) yang tepat terhadap permen jelly yang dihasilkan, diketahui bahwa perlakuan terbaik adalah perlakuan dengan konsentrasi $75 \%$ buah nipah dan $25 \%$ rumput laut. Pada perlakuan tebaik itu didapatkan kadar air sebesar 22\%, kadar gula reduksi $64,66 \%$, kadar pati $22 \%$, dan penilaian terhadap organoleptik, seperti rasa, warna, aroma, dan tekstur berkisar antara 3,5\% - 4,2\%.

Dari penelitian pendahuluan yang dilakukan bahan perbandingan antara 
bubur kacang merah dan bubur rumput laut 1:1 menghasilkan permen jelly yang dapat diterima warna, aroma, dan tekstur secara organoleptik. Dengan demikian penulis tertarik melakukan penelitian yang berjudul "Studi Perbandingan Kacang Merah (Phaseolus Vulgaris L.) dan Rumput Laut (Euchema Cottonii) terhadap Karakteristik Permen Jelly".

Tujuan dari penelitian ini adalah untuk mengetahui konsentrasi perbandingan antara kacang merah (Phaseolus Vulgaris L.) dan rumput laut (Euchema cottonii) yang tepat terhadap karakteristik permen jelly.

Manfaat dari penelitian ini adalah untuk memberikan pengetahuan kepada masyarakat mengenai manfaat dari kacang merah serta untuk memberikan alternatif kepada masyarakat cara mengolah kacang merah menjadi suatu produk pangan yang bernilai jual lebih tinggi seperti permen jelly kacang merah.1 dan rumput laut.

\section{METODOLOGI PENELITIAN}

\section{Bahan}

Bahan yang digunakan adalah kacang merah (Phaseolus vulgaris L.) Rumput laut, air, gula putih/sukrosa, air kapur. Adapun bahan yang digunakan untuk analisis kimia : aquades, $\mathrm{Pb}$-asetat, Na-Oksalat, Na-hidrat, larutan luffschool $\mathrm{KI}, \mathrm{H}_{2} \mathrm{SO}_{4}, \mathrm{Na}$ Thiosulfat, aquades, asetat, $\mathrm{Na}_{2} \mathrm{CO}_{3}, \mathrm{I} 2, \mathrm{~K}_{2} \mathrm{SO}$, $\mathrm{CuSO}_{4}-5 \mathrm{H}_{2} \mathrm{O}$, metal red, metilen blue, alkohol, indikator mengsel, $\mathrm{NaOH}$.

\section{Alat}

Alat yang digunakan dalam penelitian ini adalah panci, pisau, telenan kompor, blender, baskom, kain saring, mangkok, gelas ukur, adapun alat untuk analisa kimia yaitu: timbangan, labu takar, erlenmenyer, dan inkubator, cawan porselen, oven, desikator, timbangan, labu kjeldahl, labu suling, indikator mengsel, gelas piala, batu didih, cawan.

\section{Metode Penelitian}

Penelitian ini menggunakan metode Rancangan Acak Lengkap (RAL). Di mana terdiri dari 4 perlakuan dan 3 kali ulangan, adapun perlakuan yang dilakukan dalam penelitian ini adalah sebagai berikut :

$\mathrm{A}=\mathrm{KM} \mathrm{0 \%}: 100 \% \mathrm{RL}$

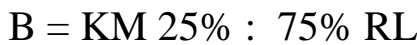

$\mathrm{C}=\mathrm{KM} 50 \%: 50 \% \mathrm{RL}$

$\mathrm{D}=\mathrm{KM} 75 \%: 25 \% \mathrm{RL}$

Ket : $\quad \mathrm{KM}=$ Kacang Merah

$\mathrm{RL}=$ Rumput Laut

Perlakuan ini diulang sebanyak $3 x$ ulangan sehingga diperoleh pula perlakuan 4 x 3 dengan jumlah 12 unit percobaan.

\section{Pelaksanaan Penelitian}

Pengolahan permen jelly kacang merah (Phaseolus vulgaris L.) terdiri dari 3 tahap proses yaitu : Proses pengolahan bubur kacang merah, proses pengolahan bubur rumput laut dan proses pengolahan permen jelly kacang merah.

\section{Proses Pembuatan Bubur Kacang Merah Secara Umum}

Dalam pembuatan bubur kacang merah terdiri dari beberapa tahapan yaitu sortasi, pencucian, perendaman, penggilingan.

1. Sortasi

Sortasi adalah pemisahan bahan baku yang masih dalam kondisi bagus dengan bahan baku yang sudah busuk atau pun yang cacat, Sortasi bertujuan untuk memilih kacang merah yang masih segar, baik dan cukup tua dengan melihat bentuk fisiknya.

2. Pencucian 
Setelah dilakukan sortasi maka selanjutnya dilakukan pencucian biji kacang merah dengan air bersih untuk menghilangkan kotoran.

3. Perendaman

Perendaman kacang merah dengan air kapur selama 24 jam bertujuan untuk melunakkan bahan, menghilangkan bau langu dan menurunkan kandungan asam fitat.

4. Pencucian

Setelah perendaman maka selanjutnya dilakukan pencucian kembali dengan air bersih agar biji kacang merah benar-benar bersih.

5. Penggilingan

Setelah dingin kacang merah kemudian dilakukan penggilingan dengan menggunakan blender guna untuk membuat bubur kacang merah.

Proses pembuatan bubur rumput laut beracuan pada (Hambali et all., 2004) yang telah dimodifikasi.

Dalam pembuatan bubur rumput laut terdiri dari beberapa tahap proses yaitu : sortasi, pencucian, perendaman, pencucian, dan penggilingan.

1. Sortasi

Sortasi yang dilakukan bertujuan untuk memilih rumput laut yang berkualitas baik dan berwarna putih bersih.

2. Pencucian

Setelah dilakukan sortasi maka selanjutnya dilakukan pencucian rumput laut yang akan digunakan hingga bersih.

3. Perendaman

Selanjutnya rumput laut kering direndam selama 12 jam menggunakan air kapur $\left(\mathrm{CaCO}_{3}\right)$ dengan konsentrasi $0,4 \%$, dengan tujuan untuk mencegah proses pencoklatan non enzimatis dan membantu mempertahankan tekstur yang akan diolah.

4. Pencucian

Setelah dilakukan perendaman maka selanjutnya rumput laut dicuci hingga bersih.

5. Penggilingan / penghalusan

Setelah rumput laut yang telah dicuci maka selanjutnya dilakukan proses penggilingan/penghalusan dengan blender ditambahkan air agar memudahkan dalam proses penggilingan.

Proses pembuatan permen jelly kacang merah beracuan (Hambali et all., 2004) yang telah dimodifikasi.

Dalam pembuatan permen jelly terdiri dari beberapa tahap proses yaitu : Persiapan bahan baku, pencampuran, pemasakan, pencetakan, pemotongan, pengeringan dan pengemasan. Persiapan bahan baku bahan yang digunakan dalam pembutan permen jelly kacang merah disiapkan sesuai dengan perlakuan.

1. Pencampuran

Pencampuran dilakukan dengan cara memasukkan bubur kacang merah kedalam campuran bubur rumput laut dan gula. Pada penelitian ini gula yang digunakan sebanyak 250 gram dengan perbandingan bubur kacang merah dan bubur rumput laut sebanyak 250 gram.

2. Pemasakan

Bubur rumput laut, bubur kacang merah, gula, yang telah di campur di masak, kemudian di aduk hingga mengental selama 20 menit dengan suhu $70^{\circ} \mathrm{C}$.

3. Pencetakan

Larutan yang telah masak kemudian dimasukkan kedalam cetakan dan didinginkan selama 1 jam dengan suhu ruang $27-32{ }^{\circ} \mathrm{C}$.

4. Pengeringan 
Permen jelly dikeringkan dibawah sinar matahari selama 5 hari dengan waktu 7 jam.

5. Pengemasan

Selanjutnya permen jelly tersebut dikemas kedalam gelas plastik agar tetap higienis.

\section{Parameter Pengamatan}

Parameter yang diamati dalam penelitian ini adalah : kadar air, kadar gula reduksi, kadar abu, dan uji organoleptik.

\section{HASIL DAN PEMBAHASAN}

\section{Kadar Air}

Analisa kadar air pada permen jelly dilakukan untuk mengetahui jumlah kandungan kadar air yang terdapat pada permen jelly kacang merah. Pada lampiran 4 menunjukkan bahwa perlakuan perbandingan kacang merah dan rumput laut memberikan pengaruh yang berbeda nyata terhadap kadar air permen jelly. Dari analisa sidik ragam menunjukkan bahwa $\mathrm{F}$ hitung lebih besar dari $F$ tabel $(15,90>4,07)$ maka dilakukan uji lanjut taraf 5\%. Hasil kadar air pada permen jelly kacang merah dapat dilihat pada tabel 1 .

Tabel 1. Kadar Air Terhadap Permen Jelly Kacang Merah dan Rumput Laut Yang Dihasilkan

\begin{tabular}{|c|cc|}
\hline Perlakuan & \multicolumn{2}{|c|}{ Kadar Air(\%) } \\
\hline D = kacang merah 75\% : 25\% rumput laut & $22,44 \quad$ A \\
\hline C = kacang merah 50\% :50\% rumput laut & $22,95 \quad$ A B \\
\hline A = kacang merah 0\% :100\% rumput laut & 24,57 & C \\
\hline B = kacang merah 25\%: 75\% rumput laut & 24,69 & $\mathrm{C}$ \\
\hline
\end{tabular}

Keterangan : Angka-angka yang diikuti oleh huruf dan pada kolom yang sama berarti berbeda sangat tidak nyata menurut uji BNT taraf $5 \%$.

Pada tabel 1 kadar air tertinggi diperoleh dari perlakuan B (25\% kacang merah : $75 \%$ rumput laut) dan kadar air terendah pada perlakuan D (75\% kacang merah : $25 \%$ rumput laut). Dapat disimpulkan bahwa semakin banyak jumlah kacang merah yang ditambahkan maka akan semakin rendah jumlah kadar air yang ada pada permen jelly, hal ini karena kacang merah mengandung karbohidrat. Di mana karbohidrat mempunyai sifat mengikat air sehingga dapat mengurangi kadar air pada bahan yang ditambahkan. Aktivitas air dari bahan pangan yang juga berkurang karena pengaruh penambahan gula dalam konsentrasi yang tinggi, hal demikian terjadi pada pembuatan permen (Hasniarti, 2012). Secara keseluruhan kadar air A $(24,57)$, B $(24,69), C(22,95)$, dan D $(22,44)$ tidak memenuhi SNI 2008 dimana batas maksimum $20 \%$.

\section{Kadar Gula Reduksi}

Analisa kadar gula reduksi pada permen jelly dilakukan untuk mengetahui jumlah kandungan kadar gula reduksi yang terdapat pada permen jelly kacang merah. Pada lampiran 6 menunjukkan bahwa perlakuan perbandingan kacang merah dan rumput laut memberikan pengaruh yang berbeda nyata terhadap kadar gula reduksi permen jelly. Dari analisa sidik ragam menunjukkan bahwa $\mathrm{F}$ hitung lebih besar dari $F$ tabel $(7,02>4,07)$ maka dilakukan uji lanjut taraf 5\%. Hasil 
pengamatan terhadap kadar gula reduksi

lanjut dapat dilihat pada Tabel 2.

permen jelly kacang merah setelah uji

Tabel 2. Kadar Gula Reduksi Terhadap Permen Jelly Kacang Merah

\begin{tabular}{|c|c|}
\hline Perlakuan & Kadar Gula Reduksi (\%) \\
\hline A = kacang merah 0\%: 100\% rumput laut & $17,12 \quad$ a \\
\hline B = kacang merah 25\%: 75\% rumput laut & $18,12 \quad$ a b \\
\hline C = kacang merah 50\%: 50\% rumput laut & $19,10 \quad$ b c \\
\hline D = kacang merah 75\%: 25\% rumput laut & $19,66 \quad$ c \\
\hline
\end{tabular}

Keterangan : Angka-angka yang diikuti oleh huruf dan pada kolom yang sama berarti berbeda tidak nyata menurut uji BNT taraf 5\%

Dari tabel 2 kandungan kadar gula reduksi yang tinggi terdapat pada perlakuan D (75\% kacang merah : $25 \%$ rumput laut) dengan skor $19,66 \%$ dan kadar gula yang terendah terdapat pada perlakuan A (0\% kacang merah : $100 \%$ rumput laut) dengan skor $17,12 \%$. Menurut SNI (2008), untuk kadar gula reduksi yang terkandung dalam permen jelly kacang merah dan rumput laut adalah maksimum 25\%. Secara keseluruhan kadar gula reduksi perlakuan A $(17,12)$, B $(18,12)$, C $(19,10), \quad \mathrm{D}(19,66)$ telah memenuhi persyaratan SNI.

Tingginya kadar gula reduksi pada perlakuan D (kacang merah $75 \%$ dan rumput laut 25\%) disebabkan karena kurangnya kandungan konsentrasi penambahan ekstrak rumput laut sehingga kadar gula reduksi pada produk permen jelly D sebesar 19,66.

Dalam perlakuan A (kacang merah $0 \%$ dan rumput laut $100 \%$ ) dapat dilihat bahwa terjadi penurunan kadar gula reduksi seiring dengan semakin tingginya konsentrasi penambahan ekstrak rumput laut. Hal ini disebabkan karena serat yang terkandung pada rumput laut dapat mengikat sukrosa. Menurut Novelina, dkk (2014), dengan demikian semakin banyaknya penambahan ekstrak rumput laut, maka serat-serat pangan yang terkandung pada rumput laut semakin banyak mengikat sukrosa dan menyebabkan ketersediaan gula pada permen jelly menjadi berkurang.

Menurut Less dan Jackson (1999) kadar gula reduksi berkaitan dengan proses inversi sukrosa menjadi gula invert (glukosa dan fruktosa). Proses inversi akan terjadi karena adannya reaksi dari asam dan panas secara terpisah maupun dikombinasikan. Sukrosa dapat tereduksi menjadi glukosa dan fruktosa yang disebut gula reduksi karena adanya gugus $\mathrm{OH}$ bebas yang reaktif. Hal ini sesuai dengan pendapat Desrosier (1989) bahwa sukrosa bersifat non pereduksi karena tidak mempunyai gugus $\mathrm{OH}$ bebas yang reaktif. Selama pemasakan dengan adanya asam, sukrosa akan terhidrolisis menjadi gula invert yaitu fruktosa dan glukosa yang merupakan gula reduksi. Dari tabel 7 kandungan kadar gula reduksi yang tinggi terdapat pada perlakuan D $(75 \%$ kacang merah : $25 \%$ rumput laut) dengan skor $19,66 \%$ dan kadar gula yang terendah terdapat pada perlakuan A $(0 \%$ kacang merah : $100 \%$ rumput laut) dengan skor $17,12 \%$. Menurut SNI (2008), untuk kadar gula reduksi yang terkandung dalam permen jelly kacang merah dan rumput laut adalah maksimum 25\%. Secara keseluruhan kadar gula reduksi perlakuan A $(17,12)$, 
B $(18,12)$, C $(19,10)$, D $(19,66)$ telah memenuhi persyaratan SNI.

Tingginya kadar gula reduksi pada perlakuan D (kacang merah $75 \%$ dan rumput laut 25\%) disebabkan karena kurangnya kandungan konsentrasi penambahan ekstrak rumput laut sehingga kadar gula reduksi pada produk permen jelly D sebesar 19,66.

Dalam perlakuan A (kacang merah $0 \%$ dan rumput laut $100 \%$ ) dapat dilihat bahwa terjadi penurunan kadar gula reduksi seiring dengan semakin tingginya konsentrasi penambahan ekstrak rumput laut. Hal ini disebabkan karena serat yang terkandung pada rumput laut dapat mengikat sukrosa. Menurut Novelina, dkk (2014), dengan demikian semakin banyaknya penambahan ekstrak rumput laut, maka serat-serat pangan yang terkandung pada rumput laut semakin banyak mengikat sukrosa dan menyebabkan ketersediaan gula pada permen jelly menjadi berkurang.

Menurut Less dan Jackson (1999) kadar gula reduksi berkaitan dengan proses inversi sukrosa menjadi gula invert (glukosa dan fruktosa). Proses inversi akan terjadi karena adannya reaksi dari asam dan panas secara terpisah maupun dikombinasikan. Sukrosa dapat tereduksi menjadi glukosa dan fruktosa yang disebut gula reduksi karena adanya gugus $\mathrm{OH}$ bebas yang reaktif. Hal ini sesuai dengan pendapat Desrosier (1989) bahwa sukrosa bersifat non pereduksi karena tidak mempunyai gugus $\mathrm{OH}$ bebas yang reaktif. Selama pemasakan dengan adanya asam, sukrosa akan terhidrolisis menjadi gula invert yaitu fruktosa dan glukosa yang merupakan gula reduksi.

\section{Kadar Abu}

Menurut Fauzi (2006), bahwa kadar abu ada hubungannya dengan mineral suatu bahan. Pengujian kadar abu ini bertujuan untuk mengetahui kandungan mineral dalam suatu produk. Hasil analisa sidik ragam menunjukkan bahwa pencampuran kacang merah dan rumput laut memberikan pengaruh yang berbeda sangat nyata dengan $F$ hitung lebih besar dari $\mathrm{F}$ tabel $(8,55>4,07)$, maka dilakukan uji lanjut BNT taraf nyata $5 \%$. Hasil pengamatan terhadap kadar abu permen jelly kacang merah setelah uji lanjut dapat dilihat pada tabel 3.

Tabel 3. Kadar Abu Terhadap Permen Jelly Kacang Merah

\begin{tabular}{|c|cc|}
\hline Perlakuan & \multicolumn{3}{|c|}{ Kadar Abu (\%) } \\
\hline A = kacang merah 0\%: 100\% rumput laut & 0,84 & $\mathrm{~A}$ \\
\hline $\mathrm{B}$ = kacang merah 25\%: 75\% rumput laut & 0,98 & $\mathrm{~B}$ \\
\hline $\mathrm{D}$ = kacang merah 75\%: 25\% rumput laut & 0,98 & $\mathrm{~B}$ \\
\hline $\mathrm{C}$ = kacang merah 50\%: 50\% rumput laut & 1,01 & $\mathrm{C}$ \\
\hline
\end{tabular}

Keterangan : Angka-angka yang diikuti oleh huruf dan pada kolom yang sama berarti berbeda sangat tidak nyata menurut uji BNT taraf 5\%.

Tabel 3. Menunjukkan bahwa kadar abu permen jelly kacang merah yang tertinggi adalah perlakuan $\mathrm{C}$ (kacang merah $50 \%$ dan rumput laut $50 \%$ ) yaitu 1,012 dan kadar abu terendah terdapat pada perlakuan A (kacang merah $0 \%$ dan rumput laut $100 \%$ ) yaitu
0,844. Menunjukkan bahwa perlakuan A berbeda sangat nyata dengan perlakuan B, D, C, perlakuan B berbeda tidak nyata dengan perlakuan $\mathrm{D}$, tapi berbeda sangat nyata dengan perlakuan $\mathrm{C}$ dan $\mathrm{A}$, perlakuan $D$ berbeda sangat nyata dengan perlakuan $\mathrm{C}$ dan $\mathrm{A}$, tapi berbeda 
tidak nyata dengan perlakuan B. Dapat disimpulkan bahwa semakin tinggi konsentrasi kacang merah yang ditambahkan maka kadar abu semakin meningkat. Hal ini disebabkan karena kacang merah memiliki kandungan mineral yang cukup tinggi.

Pada perlakuan $\mathrm{D}$ mineral yang ada pada kacang merah mengalami pengurangan setelah dipanaskan dalam pembuatan permen jelly. Menurut Pramita (2008), pengolahan dengan panas secara umum dapat mengakibatkan kehilangan beberapa zat gizi dan mineral. Adanya degradasi ataupun penyusutan terhadap unsur mineral yang dikandung oleh bahan pangan yang diolah. Rendahnya kadar abu permen jelly dapat disebabkan minimnya kandungan komponen anorganik dalam bahan-bahan penyusunnya (Minifie, 1989).

Menurut Hunaefi (2002) tinggi atau rendah kadar abu permen jelly disebabkan kandungan senyawa anorganik dalam bahan penyusunnya. Selanjutnya, menurut Winarno (2008) menyatakan bahwa kadar abu suatu produk pangan berkaitan dengan mineral yang terkandung di dalam bahan tersebut. Secara keseluruhan besarnya kadar abu yang dikandung oleh permen jelly dengan perlakuan $\mathrm{A}, \mathrm{B}, \mathrm{C}$ dan D masih memenuhi persyaratan yang ditetapkan oleh Standar Nasional Indonesia (SNI) yaitu maksimal 3\%.

\section{Uji Organoleptik}

Uji organoleptik pada penelitian ini meliputi uji rasa, warna, aroma, dan tekstur. Hasil uji organoleptik pada penelitian ini dapat dilihat pada Tabel 4.

Tabel 4. Rata-rata Uji Organoleptik pada Permen Jelly Kacang Merah

\begin{tabular}{|c|c|c|c|r|}
\hline Pengujian & $\begin{array}{c}\text { A (kacang } \\
\text { merah 0\% dan } \\
\text { rumput laut } \\
100 \%)\end{array}$ & $\begin{array}{c}\text { B (kacang } \\
\text { merah 25\% } \\
\text { dan rumput } \\
\text { laut 75\%) }\end{array}$ & $\begin{array}{c}\text { C (kacang } \\
\text { merah 50\% } \\
\text { dan rumput } \\
\text { laut 50\%) }\end{array}$ & $\begin{array}{c}\text { D (kacang } \\
\text { merah 75\% } \\
\text { dan rumput } \\
\text { laut 25\%) }\end{array}$ \\
\hline Rasa & 3,55 & 3,70 & 4,15 & 3,95 \\
\hline Warna & 3,20 & 3,65 & 3,90 & 3,80 \\
\hline Aroma & 3,10 & 3,35 & 4,20 & 3,55 \\
\hline Tekstur & 3,65 & 3,70 & 4,15 & 3,90 \\
\hline
\end{tabular}

Tabel 4 menunjukkan bahwa perbandingan kacang merah dan rumput laut dalam pembuatan permen jelly berkisar antara 3,55-4,15\%. Perlakuan yang paling disukai terdapat pada perlakuan C (kacang merah 50\% dan rumput laut $50 \%$ ) dengan skor $4,15 \%$ dan rasa yang kurang disukai terdapat pada perlakuan A (kacang merah $0 \%$ dan rumput laut $100 \%$ ) dengan skor 3,55\%. Dari tabel diatas menunjukkan perlakaun A berbeda tidak nyata dengan perlakuan $\mathrm{B}$, tapi berbeda nyata dengan perlakuan D dan C, perlakuan B berbeda tidak nyata dengan perlakuan $\mathrm{D}$, tapi berbeda nyata dengan perlakaun $\mathrm{C}$ dan $\mathrm{A}$, perlakuan $\mathrm{D}$ berbeda nyata dengan perlakaun $\mathrm{C}$ dan $\mathrm{A}$, tapi berbeda tidak nyata dengan perlakuan B. Hal ini menunjukkan bahwa tingkat kesukaan panelis terhadap parameter rasa cendrung meningkat, dengan semakin sedikit penambahan rumput laut dan pebandingan kacang merah semakin meningkat maka akan menimbulkan rasa yang khas pada permen jelly.

Menurut Fitriyono (2010) bahwa sukrosa merupakan senyawa kimia yang 
memiliki rasa manis, berwarna putih dan larut dalam air. Fungsi utama sukrosa sebagai pemanis mengandung peranan yang penting karena dapat meningkatkan penerimaan rasa dari suatu makanan. Hal ini disebabkan karena formula ini mempunyai rasa perpaduan yang seimbang pada penambahan suatu produk, sehingga menghasilkan rasa yang enak dan segar.

Tabel 4 juga menunjukkan bahwa tingkat kesukaan panelis terhadap warna permen jelly kacang merah berkisar 3,2 $3,9 \%$. Warna paling disukai panelis terdapat pada perlakuan $\mathrm{C}$ (kacang merah $50 \%$ dan rumput laut 50\%) dengan skor $3,9 \%$ dan warna yang kurang disukai terdapat pada perlakuan A (kacang merah 0\% dan rumput laut $100 \%$ ) dengan skor 3,2\%. Kesukaan panelis terhadap warna permen jelly kacang merah cendrung semakin meningkat dengan semakin meningkatnya bubur kacang merah yang digunakan dalam pembuatan permen jelly, Hal ini disebabkan karena panelis lebih menyukai warna merah yang dikarenakan penambahan kacang merah yang lebih banyak dibandingkan dengan rumput laut. Menurut Cahyani (2011) warna merah pada kacang merah diharapkan bisa menjadi pewarna alami agar tidak pucat.

Hasil penelitian ini sejalan dengan penelitian yang dilakukan oleh Santoso (2007), dimana semakin banyak rumput laut maka akan menyebabkan warna menjadi keruh. Warna khas dari kappakaragenan berwarna agak gelap dan mempunyai tekstur yang mudah retak dibandingkan iota-karagenan (Fardiaz, 1989). Warna khas dari rumput laut (karagenan) yang ditambahkan dengan bahan-bahan pembuat permen jelly menghasilkan warna yang jernih dan transparan yang tidak terlalu berbeda jauh dengan warna asli dari karagenan tersebut.

Sedangkan tingkat kesukaan panelis terhadap aroma permen jelly kacang merah yang ditunjukkan tabel 4, berkisar 3,1 - 4,2 \%. Aroma paling disukai panelis terdapat pada perlakuan C (kacang merah $50 \%$ dan rumput laut $50 \%$ ) dengan skor $4,2 \%$ dan aroma yang kurang disukai terdapat pada perlakuan A (kacang merah 0\% dan rumput laut $100 \%$ ) dengan skor 3,1\%. Dari tabel diatas menunjukkan perlakuan A berbeda tidak nyata dengan perlakaun $\mathrm{B}$, tapi berbeda sangat nyata dengan perlakaun D dan C, perlakuan B berbeda tidak nyata dengan perlakuan $\mathrm{D}$, tapi berbeda sangat nyata dengan perlakuan $\mathrm{C}$ dan A, perlakuan $\mathrm{D}$ berbeda tidak nyata dengan $\mathrm{C}$ dan $\mathrm{B}$, tapi berbeda sangat nyata dengan perlakuan A. Hal ini disebabkan karena semakin meningkatnya bubur kacang merah yang ditambahkan maka akan semakin kuat aroma yang dihasilkan pada permen jelly.

Menurut Nataliningsih (2007) aroma kacang merah yaitu berbau agak langu. Hal ini terjadi karena kacang merah mengandung enzim lipoksigenase yang menghasilkan beany flavor atau bau langu, sedangkan rumput laut tidak memiliki aroma yang khas baik itu sebelum ataupun setelah pengolahan (Istini dkk., 2003). Maka dari itu, permen jelly yang dihasilkan dengan perbandingan kacang merah dan rumput laut memiliki aroma yang khas namun tidak terlalu kuat.

Dari tabel 4 juga terlihat bahwa tingkat kesukaan panelis terhadap tekstur permen jelly kacang merah berkisar 3,65 $-4,15 \%$. Tekstur paling disukai panelis terdapat pada perlakuan C (kacang merah $50 \%$ dan rumput laut 50\%) dengan skor $4,15 \%$ dan tekstur yang kurang disukai terdapat pada perlakuan 
A (kacang merah $0 \%$ dan rumput laut $100 \%$ ) dengan skor $3,65 \%$. Hal ini disebabkan karena semakin meningkatnya bubur kacang merah yang ditambahkan maka akan semakin tinggi tingkat kesukaan panelis.

Kacang merah bisa berfungsi sebagai bahan pengikat karena kacang merah mengandung protein yang tinggi (Cahyani, 2011). Kemampuan protein untuk mengikat komponen-komponen bahan pangan, seperti air dan lemak, sangat penting dalam formulasi makanan. Kapasitas pengikatan ini mempengaruhi daya lekat, pembentukan flamen dan serat. Menurut Hartayani dan Retnaningsih (2006), semakin tinggi tingkat penambahan kacang merah maka semakin tinggi tingkat kelengketan karena kacang merah mengandung kadar amilopektin sebanyak 71\%. Menurut Matz (1984) dalam Estiasih (2006) amilopektin yang tinggi akan membentuk gel yang tidak kaku.

Tekstur permen jelly yang dihasilkan dipengaruhi oleh beberapa faktor yaitu kadar air, konsentrasi gula dan $\mathrm{pH}$. Kadar air yang tinggi pada produk akan mempengaruhi tekstur menjadi lembut, Konsumen menyukai bahan pangan yang agak basah serta mudah dikunyah (Purnomo, 1995).

\section{KESIMPULAN DAN SARAN}

\section{Kesimpulan}

Dari hasil penelitian yang telah dilakukan dalam pembuatan permen jelly kacang merah (Phaseolus Vulgaris L.) dan Rumput Laut (Euchema Cottonii), maka dapat ditarik kesimpulan bahwa perlakuan terbaik terdapat pada $\mathrm{C}$ (kacang merah $50 \%$ dan rumput laut $50 \%$ ) dengan kadar air total 22,95\%, kadar gula reduksi $19,10 \%$, kadar abu $1,012 \%$, dan hasil uji organoleptik rasa
$4,15 \%$, warna $3,9 \%$, aroma $4,2 \%$ dan tekstur $4,15 \%$.

\section{Saran}

Pada pembuatan permen jelly kacang merah dan rumput laut belum menghasilkan permen dengan kadar air yang sesuai standar SNI, sehingga perlu adanya penelitian lanjut dengan menggunakan konsentrasi air yang tepat.

\section{DAFTAR PUSTAKA}

[AOAC]. Asseocation Of Official Analitical Chermis. 2005. Official Method Of Analiysis (18 Edn). Assoacation Of Official Analytical Chemist Inc. Mayland. USA.

Aisyah A. 2011. Pengaruh Perbandingan Zat Penstabil dan Konsentrasi Yoghurt terhadap Mutu Permen Jelly. Fakultas Pertanian. Universitas Sumatera Utara.

Aisyah S. 2016. Evaluasi Sifat Fisik Dan Sensori Flakes Pati Garut Dan Kacang Merah Dengan Penambahan Tiwul Singkong. Fakultas Pertanian. Universitas Lampung.

Alfianingsi A. 2011. Kualitas Karaginan Rumput Laut Jenis Eucheuma Spinosum Di Perairan Desa Punaga Kabupaten Takalar. Fakultas Ilmu Kelautan Dan Perikanan. Universitas Hasanuddin Makassar.

Amora S. Sukesi. 2013. Ekstraksi Senyawa Antioksidan Pada Nugget Rumput Laut Merah (Eucheuma Cottonii). Fakultas Matematika Dan Ilmu Pengetahuan Alam. Institut Teknologi Sepuluh Nopember Surabaya.

Astuti N. 2016. Studi Perbandingan Labu Siam (Sechium Edule Sw) dan Rumput Laut (Euchema Cottonii) terhadap Mutu Permen Jelly. Fakultas Pertanian. 
Universitas Islam Indragiri.

Badan Pusat Statistik. 2016. Pertanian dan Pertambangan. http://www.bps.go.id.

Diakses pada tanggal 5 Februari 2016.

Buckle KA, Edwadrs RA, Fleeet G H, Wooton M.1987 ilmu pangan. Hari p. Adiono, penerjemah. Jakarta : UI-prees. Terjemahan : food science.

Cahyani, Kinanthi Diah. 2011. Kajian Kacang Merah (Phaseolus Vulgaris, L) Sebagai Bahan Pengikat dan Pengisi Pada Sosis Ikan Lele. Universitas Sebelas Maret : Surakarta.

Desrosier N. W. 1989. Teknologi Pengawetan Pangan. Penerjemah M. Muljoharjo. UI Press. Jakarta

Dharma I. S, Dewi A, Darmasetiyawan I. 2016. Pelatihan Pengolahan Produk Rumput Laut Untuk Mendukung Pengembangan Nusa Lembongan Sebagai Destinasi Wisata. Fakultas Kelautan dan Perikanan. Universitas Udayana.

Dwi E, Dahlan M, Wahyuning D. 2015. Pengaruh Lama Perendaman Daging Dalam Air Kapur Sirih (Ca(Oh)2) Pada Pembuatan Bakso Daging Kelinci Terhadap Uji Ph, Kadar Air Dan Organoleftik. Fakultas Peternakan. Universitas Islam Lamongan.

Ega L. Gracia C. Meiyasa F. 2016. Kajian Mutu Karaginan Rumput Laut Eucheuma Cottonii Berdasarkan Sifat Fisiko-Kimia Pada Tingkat Konsentrasi Kalium Hidroksida $(\mathrm{KOH})$ Yang Berbeda. Fakultas Pertanian. Universitas Pattimura.

Estiasih, T. 2006. Teknologi dan Aplikasi Polisakarida Dalam Pengolahan Pangan. Universitas Brawijaya: Malang.
Fardiaz S. 1989. Hidrokoloid. Laboratorium Kimia dan Biokimia Pangan PAU IPB. Bogor.

Hambali E, Suryani A, Wadli. 2004. Membuat Aneka Olahan Rumput Laut. PT Penebar Swadaya. Jakarta Huda T, Titi H.P. 2015. Mempelajari Pembuatan Nugget Kacang Merah. Fakultas Pertanian. Universitas Yudharta Pasuruan.

Kartika B. P, Hastuti W, Supartono. 1988. Pedoman Uji Indrawi Bahan Pangan. Pusat Antar Universitas Pangan Dan Gizi. Universitas Gajah Mada. Yogyakarta.

Lutony, Tony L. 1993. Tanaman Sumber Pemanis. PT. Penebar Swadaya. Jakarta.

Meilisa R. 2015. Pengaruh Perbandingan Gula Pasir (Sukrosa) Dengan Gula Merah (Gula Aren) Terhadap Karakteristik Noga Kacang Hijau (Phaseolus Radiatus L). Fakultas Teknik. Universitas Pasundan Bandung.

Nataliningsih. 2007. Analisa Sifat Fisiko-kimia Pengolahan BMC Instan Dalam Rangka Penanggulangan Gizi Buruk di Pedesaan (Laporan Penelitian). Universitas Bandung Raya: Bandung

Nila D.S. 2016. Pengaruh Penggantian Tepung Terigu Dengan Tepung Kacang Merah (Phaseolus Vulgaris L.) Terhadap Sifat Organoleptik Kulit Siomay. Fakultas Teknik. Universitas Negeri Surabaya.

Nurrahmi L. 2017. Pengaruh Penambahan Cangkang Telur Terhadap Karakteristik Permen Jelly Susu Kedelai. Fakultas Teknologi Pertanian. Universitas Andalas Padang.

Poncomulyo, T., Maryani, H. \& Kristiani, L. 2006. Budidaya dan 
Pengolahan Rumput Laut. Jakarta: Agro Media Pustaka.

Praptiningrum W. 2015. Eksperimen Pembuatan Butter Cookies Tepung Kacang Merah Substitusi Tepung Terigu. Fakultas Teknik. Universitas Negeri Semarang.

Purnomo H. 1995. Aktivitas Air Dan Peranannya Dalam Pengawetan Pangan. UI.

Rukmana, R. 2009. Buncis. Kanisius. Yogyakarta.

Santoso, D. 2007. Pemanfaatan Rumput Laut Gellidium sp. dalam Pembuatan Permen Jelly.Skripsi.Program Studi Teknologi Hasil Perikanan, Fakultas Pertanian, Institut Pertanian Bogor. Bogor. (Tidak Dipublikasikan).

Sari. 2014. Pengaruh jenis gula yang berbeda terhadap mutu permen jelly rumput laut [skripsi]. Fakultas Pertanian. Universitas Islam Indragiri.

SNI (Standar Nasional Indonesia) 3574.2-2008. Mutu Kembang Gula Lunak. Badan Standarisasi Nasional, Jakarta.

SNI (Standar Nasional Indonesia). 0131440.2005. Gula Kristal Putih. Jakarta: Badan Standarisasi.

Sriwahyuni, Dian dan Mardesci, Hermiza. 2017. Studi Konsentrasi Bubur Buah Nipah (Nypa fruticans wurmb) dan Rumput Laut (Euchema cottoni) yang Tepat terhadap Permen Jelly yang Dihasilkan. Jurnal Teknologi Pertanian. Universitas Islam Indragiri. Vol.6, No.2, Tahun 2017. Pp: 41-49. ejournal.unisi.ac.id.

Standar Nasional Indonesia 3547. 2. 2008. Revisi Kembang Gula Lunak (Jelly) Departemen Perindustrian.

Sudarmadji S, Haryono B, \& Suhardi., 1997. Prosedur Analisa untuk Bahan Makanan dan Pertanian. Penerbit Liberty, Yogyakarta.

Suekarto T, S. 1985. Penelitian Organoleftik Untuk Industri Pangan Dan Hasl Pertanian. Bhtera Karya Aksara. Jakarta

Sulardjo, Santoso A. 2012. Pengaruh Konsentrasi Gula Pasir Terhadap Kualitas Jelli Buah Rambutan. Fakultas Teknologi Hasil Pertanian. UNWIDHA Klaten.

Surni W. 2014. Pertumbuhan Rumput Laut (Eucheuma Cottonii) Pada Kedalaman Air Laut Yang Berbeda. Program Studi Pendidikan Biologi. Universitas Maluku.

Winarno F G. 2004. Kimia Pangan dan Gizi. PT. Gramedia Pustaka Utama. Jakarta. 